\title{
ДОВІРА В СИСТЕМІ ПРОФЕСІЙНОЇ ДІЯЛЬНОСТІ СОЦІАЛЬНИХ ПРАЦІВНИКІВ У ГРОМАДІ
}

Розкривається роль довіри в конструюванні форм і змісту сучасної соціальної роботи в громаді, яка б відповідала актуальному соціальному замовленню. Показано, що соціальна робота в громаді завдяки своїм повсякденним практикам наділена ресурсом трансформації міжособистісної довіри в інституційні форми соціальної довіри i, таким чином, спрямована на розв'язання комплексних соціальних проблем, зумовлених невизначеністю майбутнього в постмодерному суспільстві, що трансформується і переживає багаторівневу кризу. У міждисциплінарному науковому дискурсі феномен довіри “вплітається“" в тематику соціального капіталу та соціального благополуччя як їхня складова, умова i наслідок. Обстоюється думка, що об’єднавчий (від англ. bridging “той, що будує мости”) соціальний капітал дає змогу мобілізувати додаткові ресурси людських відносин на основі довіри і зв'язків, тобто нарощування соціального капіталу спільноти зміцнює іï, забезпечуючи згуртованість людей у громаді. Наголошується на тому, що чим більший радіус довіри (коло осіб чи соціальних груп, що становлять єдину систему довірчих стосунків), тим потужніший соціальний капітал громади. Представлено результати аналізу змісту групових дискусій і поділених рефлексій навколо феноменологічних смислів довіри та чинників, що впливають на становлення довіри і взаєморозуміння в місцевих громадах (дослідження здійснювалося на партисипативній основі під час фасилітації програми “Активні громадяни” Британської ради). На основі використання методології феноменологічного і конструктивістського підходів, методик партисипативного дослідження зроблено висновок про те, що взаємовідносини довіри $є$ сутністю соціальної роботи в громаді і водночас іiі метою, засобом, принципом і ресурсом, а в контексті професійної діяльності - ще й важливою компетенцією.

Ключові слова: довіра, соціальний капітал, громада, професійна діяльність соціальних працівників.

Постановка проблеми. Складний, мінливий, трансформаційний контекст сьогодення часто є для людей непрозорим, а тому стає для них незрозумілим і викликає недовіру. Для того щоб виживати і функціонувати в суспільстві, люди повинні постійно тестувати навколишній світ у пошуках тих осіб, засобів, продуктів, організацій, ідей, які будуть їм потрібні, корисні, необхідні. І тут на допомогу приходить довіра, що стає "містком над прірвою невпевненості, протезом, який дає змогу почуватися впевненіше у невизначеному світі” [8, с. 30]. Тому, виступаючи інструментом переходу в невизначене i невідоме майбутнє, довіра як соціокультурний ресурс є найважливішим феноменом 3 тих, що визначають благополуччя людей і суспільства. 
Проблемі довіри науковці останнім часом приділяють усе більше уваги. Це зумовлено загальним зниженням довіри між людьми в суспільстві через загострення соціально-економічної ситуації у світі та окремих країнах. Для України, як і інших країн постсоціалістичного табору, втрата довіри в суспільстві, що потрапило у вир знаменних історичних подій, стала наразі вкрай актуальною проблемою. П. Штомпка оцінює радикальні соціальні зміни пострадянського періоду як глибоку суспільну трансформаційну травму, що викликала руйнування соціальної довіри [8].

Діяльність соціальних працівників як форма соціальної допомоги ставить за мету підтримку можливостей клієнта (людини, сім'ї чи громади) аби допомогти йому самостійно долати труднощі в різних сферах життєдіяльності. В основі такої діяльності лежить довірлива взаємодія як взаємозв'язок суб'єктів діяльності в процесі сумісного пошуку способів розв'язання проблеми, довіра як позитивне ставлення до того, що відбувається.

Соціальна робота з розвитку громад, що перебуває наразі в Україні на етапі становлення, інституціоналізується переважно в громадському секторі за підтримки міжнародних агенцій. Рівень громади надає професійній діяльності соціального працівника політико-психологічного змісту, оскільки передбачає вплив на владно-підвладні відносини i взаємодію. Фахівці з розвитку місцевих громад ставлять перед собою, зокрема, такі завдання:

- нарощування здатності населення до спільних позитивних дій шляхом навчання і консультування (capacity building);

- наділення населення владою над умовами свого життя (community empowerment), перетворення місцевих жителів з об'єктів впливу на суб'єктів взаємодії, розвиток партисипативної демократії і залучення жителів у процеси розвитку території (enhanced participation);

- конструювання відносин довіри, солідарності, партнерства, взаємної поваги між людьми на локальному рівні, підсилення готовності людей до співробітництва, формування у жителів почуття належності, усвідомлення ними спільності інтересів, генерування соціальних зв'язків (нарощування соціального капіталу), протидія соціальній ізоляції.

Довіра $\epsilon$ ключовою категорією для розуміння соціально-психологічної сутності професійної діяльності соціального працівника. Вона характеризується передусім тим, що спрямована на майбутні перетворення ситуації клієнта (індивіда, сім'ї, групи, громади), які відбуваються в повсякденному житті у відносинах з іншими. Соціальна робота в громаді завдяки своїм повсякденним практиам наділена ресурсом трансформації міжособистісної довіри в інституційні форми соціальної довіри.

Аналіз останніх досліджень $і$ публікацій. Огляд літератури 3 досліджуваної проблеми показує, що довіра як багатоаспектне явище вивчається з різних сторін. Довіру розглядають як почуття, очікування, 
стан, уявлення, психологічне ставлення, здібність, процес тощо. Нерідко довіру трактують як форму соціальної компетентності (уміння і готовність будувати довірчі стосунки), частину загальної культури (сукупність правил і норм). Окрему увагу звернемо на розуміння довіри в контексті соціальної психології як партнерських взаємовідносин, що формуються на основі зіставлення взаємних оцінок, настановлень, очікувань. Наразі довіру все частіше вважають властивістю міжособистісних відносин, атрибутом суспільно-індивідуального поля, в якому функціонують люди. Наприклад, практичні аспекти довіри в професійній діяльності працівників соціальних служб, особливості та чинники налагодження і підтримки довірливих відносин у системі “соціальний працівник - клієнт" на індивідуальному рівні в межах конкретної соціальної служби дослідила I. М. Крючкова [3].

У науковому дискурсі різного предметного спрямування (політологічного, соціально-філософського, соціологічного, економічного, соціально-психологічного та ін.) феномен довіри щільно поєднується 3 тематикою соціального капіталу та соціального благополуччя як їхня складова, умова та наслідок $[1 ; 2 ; 4 ; 6-8]$. Так, довіра у відносинах взаємності, а також ії роль у конструюванні благополуччя стали предметом розгляду авторів книги "Наснажувальна соціальна робота: дослідження і практика" ("Empowering social work: research and practice") [10]. Цікаво, що, розглядаючи відносини довіри у зв 'язку із соціальним капіталом, автори обмежуються індивідуальним рівнем соціальної роботи та питаннями сімейної соціальної політики, оминаючи рівень громади.

Не вирімені раніше частини загальної проблеми. Невирішеною залишається проблема довіри та ії зв'язку із соціальним капіталом у системі професійної діяльності соціального працівника в громаді у процесі розв'язання актуальних соціальних проблем.

Mета статmi: висвітлення феноменологічного змісту довіри в просторі розвитку громад як важливої функції сучасної соціальної роботи в Україні.

Виклад основного матеріалу дослідження. Методологічною основою цієї розвідки стали феноменологічний і конструктивістський підходи, а інструментами - партисипативні методи дослідження, що передбачають планування та проведення дослідницького процесу разом із, за участі (від англ. participation - участь) тих людей, чий життєвий світ і значущі дії вивчаються. При цьому мета запиту i дослідницькі питання перебувають на перетині двох точок бачення - 3 перспективи як науки, так і практики.

Щоб мати ефективні результати, коли йдеться про процес розвитку громад, соціальний працівник повинен вірити, що їхні члени мають не тільки бажання, а й здатність будувати власне благополуччя за допомогою запропонованих засобів. Сподівання на ефективність своєї діяльності соціальний працівник пов'язує з довірою до себе і до громади. 
Важливим при цьому є розуміння сутності довіри, закономірностей побудови та збереження відносин взаєморозуміння в системі “соціальний працівник - клієнт" як на міжособистісному рівні, так і на рівні громади.

За П. Штомпкою [9], довіра поєднує два елементи - упевненість і її вияв у практиці, з якими пов'язані особливі очікування: довіра спирається на думку людини про поведінку іншої особи в тій чи тій ситуації в майбутньому. Довіряти - це означає передбачати майбутнє, тобто поводитися так, немовби ми впевнені у майбутньому. Однак самої передбаченої впевненості недостатньо для того, щоб можна було говорити про довіру. Довіра - це щось більше, ніж пасивні роздуми про майбутні можливості. Обов'язковою ознакою довіри є спрямованість на активне прийняття майбутнього, тобто довіра передбачає впевненість у дії. Довіра - це впевненість плюс дії, які на ній базуються, а не лише сама впевненість. Тобто довіра - це поняття із сфери активного дискурсу.

Недовіра - це дзеркальне відображення довіри, але з протилежним знаком. Поняття “недовіра” пов'язане 3 негативними очікуваннями щодо майбутніх дій інших (з ворожими передбаченнями, шкідливими або образливими діями) і передбачає налаштованість оборонятися від них (шляхом ухиляння від дій, відмови їх розпочинати, відсторонення, вжиття охоронних заходів щодо тих, до кого є недовіра). Це відбувається тоді, коли $є$ підстави вважати, що партнер не буде діяти в інтересах того, хто йому довіряє. Тим більше, коли $є$ впевненість, що він буде діяти проти його інтересів.

Термін “брак довіри” означає нейтральну ситуацію, коли до іншої людини немає як довіри, так і недовіри через несформованість власної думки про неї. Таке ставлення може скластися щодо значної кількості інших людей - невідомих або байдужих. Термін “брак довіри” використовується щодо партнерів по інтеракції в значенні початкового iii стану, поки не виникли передумови для оцінювання цього стану як довіри або недовіри. Тобто важливим аспектом розуміння феномену довіри $є$ iї соціальні межі, що можна описати "горизонтально” в континуумі “довіра-недовіра", а також у “вертикальному” ракурсі - усередині суспільної ієрархії.

Л. А. Найдьонова розглядає сучасну територіальну спільноту як "мережеве утворення, що має сутнісні рефлексивні властивості, твориться через самовизначення, переосмислення історії, здійснення індивідуальних внесків у смисл спільноти, які відбуваються в комунікації ії членів" [5, с. 241]. Звідси випливає, що побудова і зміцнення відносин довіри стають можливими в разі поділяння членами спільноти соціальних та рефлексивних практик. Об'єднуючи концепти креативного і соціального капіталів, капітал рефлексивний створює ресурси для розв'язання проблем у спільнотах, які сприяють зростанню якості життя і психологічного благополуччя спільнот [5]. 
Практикуючи впровадження програми “Активні громадяни” Британської ради (ідеться про фасилітацію понад 20 тренінгів для близько 600 учасників різного віку, соціального статусу, місця проживання, під час яких учасники потрапляли в різні ситуації рефлексії власного досвіду повсякденних соціальних відносин), авторка цієї статті мала змогу на партисипативній основі досліджувати смисли аналізованого громадськими лідерами та активістами феномену. Наводимо деякі результати аналізу змісту групових дискусій та поділених рефлексій щодо таких питань:

- Що для вас означають поняття “довіра" $i$ “взаєморозуміння”?

- Що в наших громадах перешкоджає побудові відносин довіри $i$ взаєморозуміння?

- Що в наших громадах сприяє розвитку довіри і взаєморозуміння?

У визначеннях, що продукувалися учасниками малих груп на основі спільного обговорення, довіра найчастіше постає як компетенція i ресурс (“здатність”, “спроможність”, “можливість”, “уміння”): "спроможність людини покластися на іншу особу”, "здатність людини вільно і комфортно почуватися в спільноті", “здатність відкривати іншим свій внутрішній світ і бути готовим відповідати за свої діі", “уміння допустити інших до вирішення своїх проблем”, “здатність повірити в іншу людину, відкритися їй, почути і прийняти думку іншого" та ін.

Інший модус існування довіри в уявленнях учасників тренінгів “довіра як основа $і$ передумова" суспільних відносин і досягнення змін: “основа співпрачі з іншими”, “одна з найважливіших умов позитивного результату, важлива потреба кожної людини”, “одна з передумов сталого розвитку, яка характеризується спільністю ідей, єдністю думок, пріоритетів розвитку, взаємною підтримкою, порядністю, толерантністю, визнанням рівноправності".

Довіра сприймається також як набір соціально-психологічних характеристик, що грунтуються на відносинах взаємності (“довіра як взаємовідносини”): “взаємовідносини людей, щяо базуються на порядності і позитивному ставленні", "відкритість та відчуття підтримки, упевненості в іншій людині, відсутність страху, взаємодопомога, чесність, повага до думки іншого та зворотний зв 'язок'”.

Простежується також і зв'язок з афективно-мотиваційним виміром довіри: “віра в те, що тебе не зрадять”, “бажання $і$ готовність висловити свою думку і прийняти іншу сторону”.

Можна говорити про різні рівні та виміри довіри. На міжособистісному рівні довіра сприяє задоволенню індивідуальних потреб та інтересів, забезпечуючи психологічне і життєве благополуччя окремих особистостей у процесі взаємодії з навколишнім середовищем. Корпоративні інтереси забезпечують відчуття партнерства, почуття взаємного професійного і товариського визнання, підвищення взаємовідповідаль- 
ності за стабільне становище господарюючих організацій на ринку. Що ж стосується довіри на громадському рівні, то вона задовольняє суспільний інтерес, формує громадянськість, забезпечуючи стабільність та соціальну безпеку в суспільстві.

Довіра, як культурний феномен, є важливим аспектом громадянського суспільства. Солідарна спільнота громадян, яка бере участь у політиці і має лояльних до влади громадян, не могла б існувати без горизонтальної довіри, яку виявляють громадяни взаємно один до одного, а також без вертикальної довіри до публічних інститутів.

Важливо, отже, що в переважній більшості аналізованих визначень довіра розглядається на міжособистісному рівні, тоді як соцієтальний вимір довіри 3'являється у рефлексіях щодо сильних і слабких сторін своїх громад у питаннях побудови довірчих відносин. Спостерігається слабка тенденція переваги “слабких", “проблемних" рис над “сильними” сторонами своїх громад (у загальній аналізованій сукупності 132 суб' єктивно оцінені учасниками “позитивні риси” у порівнянні зі 151 "із знаком мінус").

Аналіз результатів підтвердив також існування й функціонування аналізованого явища в суспільній свідомості у формі дихотомії “довіранедовіра”, що проявляється в діадах суб'єктивної оцінки конструктів у системі "плюс - мінус": "прагнення до спільних дій, згуртованість у критичних ситуаціях - егоцентризм населення, індивідуалізм”, “відкритість - закритість", "наявність знань - низька обізнаність”, "віра в краще, бажання змін-острах змін, зневіра", "ініціативність - безініціативність", “правда - брехня”, “підвищення авторитету влади бізнесова та владна непорядність”, "подолання корупції - кумівство $i$ процвітання корупиії” та ін.

Цікавою виявилася і рефлексія чинників, що різними групами оцінювалися як протилежні за впливом на розвиток довіри і взаєморозуміння. Наприклад, доволі часто згадуваний соцієтальний макрочинник “геополітична ситуація в країні” оцінювався одними групами як сприятливий з поясненнями на кшталт "геополітична відкритість краӥни та пов'язані з иим можливості розширення міжкультурного обміну в громадах", а іншими -як об'єктивно існуюча “загроза єдності", "ідеологічно-иіннісний розкол у суспільстві".

Ще один приклад - дискусія навколо амбівалентності соціальнопсихологічного мезочинника "різні погляди в одній громаді": чи це “стримує громаду в розвитку”, “перешкоджає виробленню поділюваного бачення і стратегії бажаного поступу до благополуччя", а чи, навпаки, співіснування і прийняття різних поглядів, ментальностей і психологій “є ознакою толерантності і переходу довіри на якісно новий рівень", виходу за межі внутрішньогрупової підтримки і розуміння, найближчого кола довіри, нарощування соціального капіталу як ресурсу громади? 
Адже для розвитку громади критично важливими є рефлексивні практики взаємодії між иленами громади - представниками різних соціальних груп, які формуються в ході тривалого історичного процесу і стають детермінантами успіху (чи неуспіху) таких спільнот [9].

Соціальний капітал громади виникає в міжособистісній взаємодії, забезпечує стабільність соціальної системи та посилює таким чином особистісні ресурси людини. Один із творців теорії соціального капіталу Р. Патнем вважає його важливим чинником політичної стабільності, ефективності урядів і навіть економічного прогресу, адже він базується на взаємності і довірі між людьми, поширенні добровільних асоціацій та залученості жителів до політики задля вирішення проблем громади [6]. На думку дослідника, громадська взаємодія на основі горизонтальної та вертикальної довіри - це більший скарб, ніж економічні ресурси, адже основними формами соціального капіталу є мережі (горизонтальні відносини), соціальні норми та інституціоналізована в соціальних практиках довіра. Соціальний капітал можна порівняти з “клеєм”, що дає змогу мобілізувати додаткові ресурси людських відносин на основі довіри і зв'язків, тобто нарощування соціального капіталу спільноти зміцнює iї, забезпечуючи згуртованість людей у громаді. Чим більший радіус довіри (коло осіб чи соціальних груп, що утворюють єдину систему довірчих стосунків), тим потужніший соціальний капітал громади, тим ширше коло “якісних" відносин між людьми.

Отже, нарощування соціального капіталу не тільки сприяє зміцненню спільнот, а й впливає на відчуття благополуччя і добробуту. Ідеться про збагачення життєвого світу членів спільноти, підвищення якості їхнього життя, суб'єктивне відчуття соціального добробуту, психічне благополуччя. Зміцнення соціального капіталу може означати: підтримку соціальних мереж, які поєднують групи; розвиток спільного відчуття належності, спільного бачення майбутнього та акцентування на тому, що спільного мають різні соціальні групи; заохочення спільної участі та активного залучення осіб із різним соціальним контекстом; побудову довіри (люди, які довіряють одне одному та місиевим інституиіям, щзо діють справедливо); виховання поваги й толерантності розвиток розуміння інших та визнання цінності різноманітності; підвищення здатності держави реагувати на потреби громадян.

Залежно від того, на які соціальні мережі покладається людина, розрізняють зв'язувальний (від англ. bonding - “той, що пов'язує”) та об'єднавчий (від англ. bridging - “той, що будує мости”) соціальний капітал. Зв'язувальний соціальний капітал - це ресурс відносин індивідів, що мають схожі характеристики (родинні чи дружні стосунки), а об'єднавчий соціальний капітал будується на основі відносин між різними соціальними групами (зв'язки в межах громадських організацій та спільнот, формальні зв'язки). Наприклад, як показало дослідження 
“Оцінка потреб внутрішньо переміщених жінок та осіб похилого віку в Україні”, проведене ГО “Український інститут соціальних досліджень імені Олександра Яременка”, ВПО частіше мають більший зв'язувальний, а не об'єднавчий соціальний капітал - соціальна підтримка та довіра всередині родинних мереж стає основним ресурсом. Підтримка родичів для ВПО дуже важлива, але вона обмежує взаємодію з місцевими громадами та інститутами, що є основним джерелом формування об'єднавчого соціального капіталу та інституціоналізації довіри в ширше коло громади. Розбудова “об'єднавчих” соціальних мереж ВПО у приймальних громадах на основі налагодження відносин довіри $\epsilon$ пріоритетним чинником їхньої успішної соціальної інтеграції [7]. На рівні практик соціальної роботи в громаді це виявляється в міжособистісному спілкуванні переселенців та місцевих жителів приймальних громад, долученні до місцевих звичаїв і традицій, проведенні спільних культурно-мистецьких заходів.

Висновки. Сприяння згуртованості громади передбачає усунення бар'єрів і заохочення до накопичення позитивного досвіду взаємодій між групами. Соціальна робота в громаді тісно пов'язана 3 нарощуванням довіри і соціального капіталу, оскільки має на меті побудову таких громад, де люди, взаємодіючи з іншими, мали б усвідомлене відчуття належності і комфорту.

3 огляду на інтерактивну сутність професійної діяльності соціальних працівників та спираючись на етичні принципи діяльності спеціалістів із соціальної роботи (принцип 4 - Довіра та взаємодія у вирішенні проблем клієнта), а також у контексті проблем, зумовлених невизначеністю майбутнього в постмодерному суспільстві, що трансформується, маємо підстави стверджувати таке: взаємовідносини довіри є сутністю соціальної роботи в громаді і водночас ії метою, засобом, принципом і ресурсом, а в контексті професійної діяльності ще й важливою компетенцією.

Перспективою подальших досліджень вважаємо когнітивне картування феноменів довіри і соціального капіталу в процесі реконструкції змісту сучасної соціальної роботи як професійної діяльності, а також узагальнення і систематизацію наявних та розвиток інноваційних соціальних практик формування довіри й нарощування соціального капіталу.

\section{Лiтература}

1. Галиуллин Д. Л. Социальное доверие и социальный капитал в региональной политике развития / Д. Л. Галиуллин // Вестник ТОГУ. - 2009. - № 2 (13). C. 221-228.

2. Звонкина О. П. Формирование социального доверия местного сообщества посредством социальных практик / О. П. Звонкина // Дискурс. - 2017. № 1. - C. 91-94. 
3. Крючкова И. М. Социально-психологические аспекты доверия в профессиональной деятельности сотрудников социальных служб / И. М. Крючкова // Человеческий капитал. - 2017. - № 8 (104). - С. 88-94.

4. Мейжис I. A. Соціальний капітал як ресурс розвитку українських міських громад / І. А. Мейжис, Ю. В. Татенко // Наукові студії із соціальної та політичної психології : зб. статей / Акад. пед. наук України, Ін-т соц. та політ. психології. - 2011. - № 26 (43). - С. 358-368.

5. Найдьонова Л. А. Рефлексивна психологія територіальних спільнот / Л. А. Найдьонова. - Київ : Міленіум, 2012. - 280 с.

6. Патнем Р. Д. Творення демократії: традиції громадянської активності в сучасній Італії / Р. Д. Патнем, Р. Леонарді, Р. Й. Нанетті. - Київ : Основа, 2001. - 302 c.

7. Середа Ю. В. Соціальний капітал внутрішньо переміщених осіб як чинник локальної інтеграції в Україні [Електронний ресурс] / Ю. В. Середа // Український соціум. - 2015. - № 3 (54). - Режим доступу : http://www.ukrsocium.org.ua/Arhiv/Stati/US-3-2015ukr/29- 41.pdf.

8. Ткачук $A$. Внутрішні та зовнішні ресурси для розвитку громади або Чому брак грошей не $є$ первинною проблемою громади? : навчальний модуль / Анатолій Ткачук, Маркіян Дацишин. - Київ : Легальний статус, 2016. - 152 с.

9. Штомпка П. Доверие - основа общества / Петр Штомпка ; пер. с пол. Н. В. Морозовой. - Москва : Логос. 2012. - 440 с.

10. Empowering Social Work: Research and Practice [Electronic resourse] / Edited by Maritta Torronnen, Olga Borodkina, Valentina Samoylova, Eveliina Heino. Kotka : Palmenia Centre for Continuing Education, University of Helsinki, 2013. - Access mode : https://helda.helsinki.fi/bitstream/handle/10138/41105/ empowering_social_work.pdf.

\section{References}

1. Galiullin, D. L. (2009). Sotsialnoye doveriye i sotsialnyy kapital v regionalnoy politike [Social Trust and Social Capital in the Regional Development Policy]. Vestnik TOGU, 2(13), 221-228 (rus).

2. Zvonkina, O. P. (2017). Formirovaniye sotsialnogo doveriya s pomoshchyu sotsialnykh setey [Social Trust Forming in the Local Community through Social Practices]. Diskurs, 1, 91-94 (rus).

3. Kryuchkova, I. M. (2017). Sotsialno-psikhologicheskiye aspekty doveriya v professionalnoy deyatelnosti sotrudnikov sotsialnykh sluzhb [Socio-psychological Aspects of Trust in the Professional Activities of Social Services' Employees]. Chelovecheskiy kapital, 8(104), 88-94 (rus).

4. Meizhys, I. A., \& Tatenko, Yu. V. (2011). Sotsialnyi kapital yak resurs rozvytku ukrainskykh miskykh hromad [Social Capital as a Resource for the Development of Ukrainian Urban Communities]. Naukovi studii iz sotsialnoi ta politychnoi psykholohii, 26(29), 358-368 (ukr).

5. Naidonova, L. A. (2012). Refleksyvna psykholohiia terytorialnykh spilnot [Reflexive Psychology of the Local Communities]. Kyiv: Milenium Publ. (ukr).

6. Patnem, R. D., Leonardi, R. \& Nanetti, R. Y. (2001). Tvorennia demokratii: tradytsii hromadianskoi aktyvnosti v suchasnii Italii [Creation of Democracy: the Traditions of Civic Activity in Modern Italy]. Kyiv: Osnova Publ. (ukr). 
7. Sereda, Yu. V. (2015). Cotsialnyi kapital vnutrishno peremishchenykh osib yak chynnyk lokalnoi intehratsii v Ukraini [The Social Capital of Internally Displaced Persons as a Factor of Local Integration in Ukraine]. Ukrainskyi sotsium, 3(54). Retrieved from http://www.ukr-socium.org.ua/Arhiv/Stati/US3-2015ukr/29- 41.pdf.

8. Tkachuk, A., \& Datsyshyn, M. (2016). Vnutrishni ta zovnishni resursy dlia rozvytku hromady, abo Chomu brak hroshei ne ye pervynnoiu problemoiu hromady [Internal and External Resources for the Community Development or Why the Lack of Money is not a Primary Community Issue]. Kyiv: Lehalnyi status Publ. (ukr).

9. Shtompka, P. (2012). Doveriye - osnova obshchestva [Trust as the Foundation of Society]. Translation from Polish by N. V. Morozova. Moskva: Logos Publ. (rus).

10. Torronnen, M., Borodkina, O., Samoylova, V., \& Heino, E. (Ed.). (2013). Empowering Social Work: Research and Practice. Kotka: Palmenia Centre for Continuing Education, University of Helsinki. Retrieved from https://helda. helsinki.fi/bitstream/handle/10138/41105/empowering_social_work.pdf.

\section{Syla T. I. Trust in the System of the Social Workers' Professional Activities in the Community}

It is revealed the role of trust in designing the forms and content of modern social work in the community, which corresponds to actual social order. It has been shown that social work in the community through its day-to-day practices is endowed with a resource of transformation of interpersonal trust into institutional forms of social trust, and thus is aimed at solving complex social problems caused by the uncertainty of the future in a postmodern society that is transforming and undergoing a multi-level crisis. In the interdisciplinary scientific discourse, the phenomenon of trust "intertwines" in the subject of social capital and social well-being as a component, condition and consequence. It is argued that united (from the "bridging") social capital enables the mobilization of additional resources of human relations on the basis of trust and connections, that is, the increase of social capital of the community strengthens it, ensuring the cohesion of people in the community. It is emphasized that the larger the radius of trust (the circle of individuals or social groups who make up a single system of trust relations), the more powerful is the social capital of the community. There are presented the results of the analysis of the content of group discussions and divided reflections around the phenomenological meanings of trust and factors, which influence on the establishment of trust and mutual understanding in local communities (the study was carried out on a participatory basis during the facilitation of the British Counsil's "Active Citizens"). Based on the use of the methodology of phenomenological and constructivist approaches, methods of participatory research, it was concluded that the relationship of trust is the essence of social work in the community and at the same time its purpose, mean, principle and resource, and in the context of professional activity, it is also an important competence.

Key words: trust, social capital, community, professional activities of social workers. 
